\title{
Efficacy of Low Level Laser Therapy on De Quervain's Tenosynovitis after Delivery
}

\author{
DARIEN A. ELSAWY, M.Sc.*; MAGDA S. MORSY, Ph.D.* and MOHAMED F. ABO EL ENIN, Ph.D.** \\ The Departments of Physical Therapy for Women's Health*, Faculty of Physical Therapy, Cairo University and \\ Obstetrics \& Gynecology**, Om Elmasryeen Hospital
}

\begin{abstract}
Background: De Quervain's Tenosynovitis is painful stenosing tenosynovitis of the first dorsal compartment of the wrist that affecting daily physical functions and baby care. So, it is necessary to decrease pain in De Quervain's tenosynovitis.
\end{abstract}

Aim of Study: To investigate the efficacy of Low level laser therapy on de Quervain's tenosynovitis after delivery.

Subjects and Methods: This study was carried upon 30 women suffering from de Quervain's Tenosynovitis after delivery. Their age ranged from 25 to 35 years old and their BMI was less than $30 \mathrm{~kg} / \mathrm{m}^{2}$. They were selected from Alshohadaa hospital- Al Monofia. The participants were randomly distributed in two groups equal in number. Study group (A) consisted of 15 women who received low level laser therapy (Wave length: $830 \mathrm{~nm}$, Energy density: $20 \mathrm{~J} / \mathrm{cm}^{2}$, Power: 30 40 , Contanous out put of $100 \%$, Irradiation rate: $1 \mathrm{~min}$ for each tender point , Beam diameter: $4 \mathrm{~mm}$ ) on the tender points of her dominant hand and then performed exercise program for 30 minutes, 3 times per week for 4 weeks. Additionally to this she adviced to wear thumb spica splint while patients of Control group (B) received exercise program for 30 minutes, 3 times per week every other day for four weeks. Additionally to this she adviced to wear thumb spica splint. All participants were evaluated by visual analogue scale, serum cortisol levels before and after treatment.

Results: At the end of the treatment course, percentage of improvement in VAS and plasma cortisol levels was significantly high in the study group compared to the control group which means that low level laser therapy was effective in alleviating pain in women suffering from de Quervain's tenosynovitis after delivery.

Conclusions: Low level laser therapy has beneficial effects in alleviating pain in women suffering from de Quervain's tenosynovitis after delivery.

Key Words: De Quervain's tenosynovitis - Low level laser therapy - Visual analogue scale - Cortisol level.

Correspondence to: Dr. Darien A. Elsawy, The Department of Physical Therapy for Women's Health, Faculty of Physical Therapy, Cairo University

\section{Introduction}

DE QUERVAIN'S tenosynovitis is a stenosing tenosynovitis of the first dorsal compartment of the wrist, affecting the extensor pollicis brevis (EPB) and abductor pollicis longus (APL) tendon sheaths [1]. De Quervain's tenosynovitis (DQV) is a painful condition that causes tenderness and soreness at the radial styloid on the radial side of the wrist [2]. Therefore, daily activities that involve wrist and thumb movements may be affected [3] Patients may find it difficult to perform tasks that require turning of the wrist and exerting force by the thumb, such as opening jars with lids, lifting a child, etc.. [4].

The estimated prevalence of de Quervain tenosynovitis is about $0.5 \%$ in men and $1.3 \%$ in women with peak prevalence among those in their forties and fifties. It may be seen more commonly in individuals with a history of medial or lateral epicondylitis. Bilateral involvement is often reported in new mothers or child care providers in whom spontaneous resolution typically occurs once lifting of the child is less frequent [5].

Specific activities that have been postulated as potential risk factors include intensive computer mouse use, trackball use and typing, as well as some pastimes, including bowling, golf, fly-fishing, piano-playing, sewing, and knitting [6]. Pregnancy and mechanical factors appear to play a role in causing this condition [7]. In the post partum period, the continued demands of the infant care may cause the symptoms to persist for as long as a year, although cessation of breast-feeding frequently results in a dramatic and quick resolution [8]

Laser therapy is one of the most commonly used physiotherapeutic treatments in physiotherapy. 
The laser reduces the conduction of pain stimuli in afferent fibres as well as vasodilatory and angiogenic effects. This results in the improvement of peripheral circulation and microcirculation. Collagen synthesis and enzyme regulation processes are also stimulated [9]. The reduction of the inflammatory process is thought to provide analgesia. Throughout the inflammatory process, in addition to an increase in endorphin synthesis, LLLT modifies chemical mediators, vasodilation, and increases the synthesis of protein [10]. On the other hand, in de Quervain's tenosynovitis, inflammation occurs in the wrist and thumb due to a repetitive strain injury or a cumulative trauma. As a result, a degenerative thickening develops in the retinaculum of the extensor covering of the first extensor compartment. Ultrasonographic measurements have shown that laser treatment reduces this degenerative thickening [11]

\section{Subjects and Methods}

\section{Subjects:}

This study carried out on thirty women after delivery complaining from de quervain's tenosynovitis in their dominant hands. They were selected randomly from out-patient clinic of the Obstetrics Department of Al Shohadaa Hospital in Monofia, from June 2020 to November 2020. Patients with diabetes, cardiovascular diseases, hypertension and osteoarthritis were excluded. The age of participants ranged from 25 to 35 years old, parity ranged from (2-4) times and their body mass index not exceed $30 \mathrm{Kg} / \mathrm{m}^{2}$. The patients were divided randomly in to two equal groups $(\mathrm{A} \& \mathrm{~B})$.

- Group A (study group) consisted of (15) women. They received low level laser therapy (10min) and exercise program (30min). 3 times per week, for 4 weeks.

- Group B (control group) consisted of (15) women. They received exercise program only $30 \mathrm{~min}, 3$ times per week, for 4 weeks.

\section{Procedures:}

\section{I- Evaluative procedures:}

- Each woman in both groups (A \& B) was asked to fill the information sheet and signed on it as her agreement to share in this study before starting the treatment course.

- Weight and height of each woman in both groups (A \& B) was taken before treatment course and BMI was calculated.
- A full instruction about VAS scale was given to each woman in both groups (A \& B). Then, each woman was asked to mark on the line according to her intensity of pain this was done before and after treatment course to detect intensity of pain of each one.

- A blood sample of $3 \mathrm{~cm}$ was drawn from each woman in both groups (A \& B) before and after treatment course and was sent to the laboratory to determine the plasma cortisol level in the blood.

- Each woman was asked to sit on arm chair. The anticubital area was cleaned with a piece of cotton immersed in alcohol. Blood sample was drawn from the anticubital vein from all subjects by disposable sterile syringe.

- All samples were collected in the morning before breakfast for all cases and were sent immediately to the laboratory center for analysis.

\section{II- Treatment procedures:}

Study group (Group A): Each patient in this group asked to sit on arm chair and rest her dominant hand on the treatment table and the tender points detected and remarkabled then the low level laser device was adjusted on the following parameters: (Wave length: 830nm, Energy density: $20 \mathrm{~J} / \mathrm{cm}^{2}$, Power: 30-40, Contanous output of $100 \%$, Irradiation rate: $1 \mathrm{~min}$ for each tender point, Beam diameter: $4 \mathrm{~mm}$ ). Protective goggles worn by patients and therapist to protect their eyes from the laser beam. After that the laser probe held perpendicular to the area to be treated (the distance between the probe and the skin will be $2.5 \mathrm{~cm}^{2}$ ), Then the laser device switched on to deliver the low level laser beam on each tender point for $1 \mathrm{~min}$. This performed to the all tender points (the total duration of treatment session is 10 minutes).

After finishing the session the LLLT device swiched off then the patient started performing strengthening and stretching exercices for the extensor pollicis brevis (EPB) and abductor pollicis longus (APL) for 30 minutes, then she asked to wear the thumb spica splint. This session repeated 3 times per week for 4 weeks.

Control group (Group B): Each patient in this group asked to perform strengthening and stretching exercises for the extensor policies brevis (EPB) and abductor pollicis longus (APL) for 30 minutes, then she asked to wear the thumb spica splint. This session repeated 3 times per week for 4 week. 


\section{Results}

\section{I- General characteristics of the patient:}

The current study was conducted on 30 participants. They were assigned into two equal groups. Study group (A) consisted of 15 participants who treated by LLLT and exercise program. Control group (B) consisted of 15 participants who received exercise program only.

There was no statistical significant difference between the two groups as regards age ( $t=0.128$, $p=0.899)$, weight $(t=-0.024, p=0.981)$, height $(t=-0.594, p=0.557)$ and BMI $(t=0.0 .573, p=0.571)$, respectively (Table 1 ).

Table (1): Demographic characteristics of all patients in two groups $(\mathrm{A} \& \mathrm{~B})$.

\begin{tabular}{lcccc}
\hline & $\begin{array}{c}\text { Group (A) } \\
(\mathrm{n}=15)\end{array}$ & $\begin{array}{c}\text { Group (B) } \\
(\mathrm{n}=15)\end{array}$ & $t$-value & $p$-value \\
\hline Age (yrs. $)$ & $28.40 \pm 2.75$ & $28.27 \pm 2.94$ & 0.128 & $0.899(\mathrm{NS})$ \\
Weight (kg.) & $76.00 \pm 5.88$ & $76.07 \pm 9.08$ & -0.024 & $0.981(\mathrm{NS})$ \\
Height $(\mathrm{cm})$ & $165.60 \pm 5.42$ & $166.87 \pm 6.23$ & -0.594 & $0.557(\mathrm{NS})$ \\
BMI $\left(\mathrm{kg} / \mathrm{m}^{2}\right)$ & $27.62 \pm 1.39$ & $27.24 \pm 2.17$ & 0.573 & $0.571(\mathrm{NS})$ \\
\hline
\end{tabular}

\section{II- Visual analogue scale for both groups $(A \& B)$ :}

By comparing the two groups (A \& B) after treatment regarding to VAS scores, it was found that, both groups showed a decrease in pain sensation after treatment, group (A) achieved $92.5 \%$ while group (B) achieved $31.06 \%$ but the percentage of decrease in VAS was more pronounced and more notable in group (A) when compared with group (B), this means that low level laser therapy was effective in decreasing pain. (Table 2 \& Fig. 1).

Table (2): Illustrate mean \pm SD for VAS scores before and after treatment for both groups (A \& B).

\begin{tabular}{lccccc}
\hline & \multicolumn{2}{c}{ Group A } & & \multicolumn{2}{c}{ Group B } \\
\cline { 2 - 3 } \cline { 5 - 5 } Variable & $\begin{array}{c}\text { Before } \\
\text { treatment }\end{array}$ & $\begin{array}{c}\text { After } \\
\text { treatment }\end{array}$ & & $\begin{array}{c}\text { Before } \\
\text { treatment }\end{array}$ & $\begin{array}{c}\text { After } \\
\text { treatment }\end{array}$ \\
\hline Mean $\pm \mathrm{SD}$ & $3.60 \pm 0.51$ & $0.27 \pm 0.46$ & & $3.67 \pm 0.49$ & $2.53 \pm 0.88$ \\
MD & 3.33 & & 1.14 \\
$t \#$ value & 26.458 & & 5.264 \\
$p$-value & 0.001 & & 0.001 \\
$\%$ of $\downarrow \downarrow$ in VAS & 92.5 & & 31.06 \\
Significance & Highly & & Highly \\
& significant & & significant \\
\hline
\end{tabular}

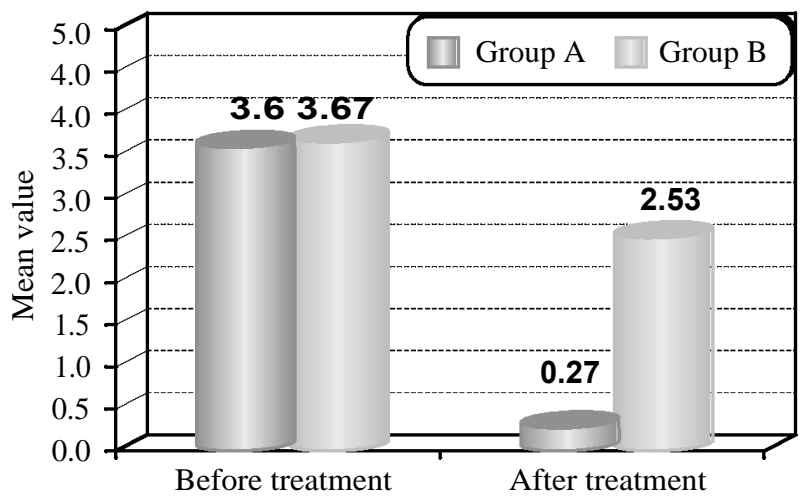

Fig. (1): Illustrates mean values of VAS measured before and after treatment in the two studied groups (A \& B).

\section{III- Serum cortisol for both groups:}

By comparing the two groups (A \& B) after treatment regarding to serum cortisol level, it was found that, both groups showed a decrease in serum cortisol level after treatment, group (A) achieved $65.31 \%$ while group (B) achieved $16.84 \%$ but the percentage of decrease in serum cortisol level was more pronounced and more notable in group (A) when compared with group (B), this means that low level laser therapy was effective in decreasing serum cortisol level. (Table 3 \& Fig. 2).

Table (3): Illustrate mean \pm SD for serum cortisol level before and after treatment for both groups (A \& B).

\begin{tabular}{lccccc}
\hline \multirow{2}{*}{ Variable } & \multicolumn{2}{c}{ Group A } & & \multicolumn{2}{c}{ Group B } \\
\cline { 2 - 3 } \cline { 5 - 6 } & $\begin{array}{c}\text { Before } \\
\text { treatment }\end{array}$ & $\begin{array}{c}\text { After } \\
\text { treatment }\end{array}$ & & $\begin{array}{c}\text { Before } \\
\text { treatment }\end{array}$ & $\begin{array}{c}\text { After } \\
\text { treatment }\end{array}$ \\
\hline Mean \pm SD & $19.63 \pm 2.90$ & $6.81 \pm 1.19$ & & $19.30 \pm 2.57$ & $16.05 \pm 2.58$ \\
MD & 12.82 & & 3.25 \\
$t \#$ value & 23.200 & & 9.155 \\
$p$-value & 0.001 & & 0.001 \\
$\%$ of $\downarrow \downarrow$ in VAS & 65.31 & & 16.84 \\
Significance & Highly & & Highly \\
& significant & & significant \\
\hline
\end{tabular}

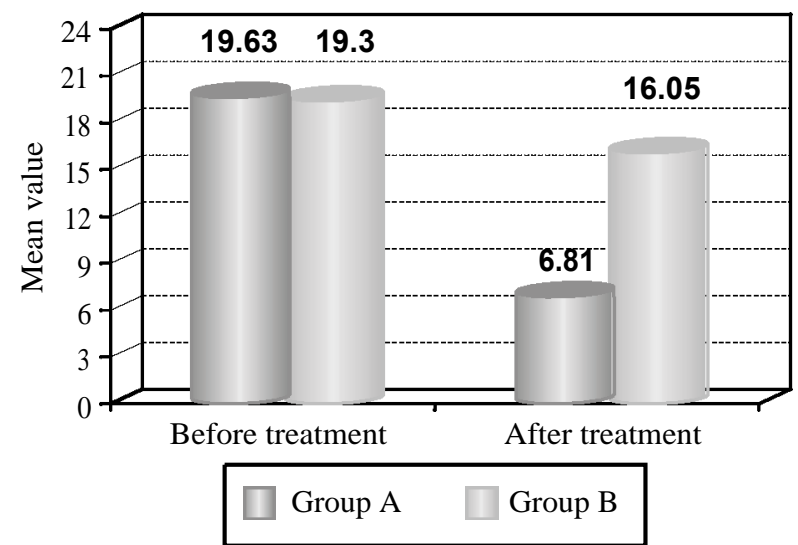

Fig. (2): Illustrates mean values of serum cortisol measured before and after treatment in the two studied groups $(\mathrm{A} \& \mathrm{~B})$. 


\section{Discussion}

This study was conducted to determine the efficacy of low level laser therapy on De Quervain's tenosynovitis after delivery. This study demonstrates that the study group which received low level laser therapy in addition to exercise program improvement in pain level than the control group which received exercise program only.

The results of this study were in agreement with papers by Tumilty et al., [12] and Stergioulas et al., [13] the laser was used in combination with the application of an eccentric exercises program, which led to clinical improvement, while for Stasinopoulos et al., [13] LLLT addintionally reported positive outcomes in parallel with an exercise program in the treatment of tendinopathy, which highlights the significance of the combination of these two therapeutic actions.

Stergioulas, [14] assessed the efficacy of LLLT and plyometric exercises in the managment of tennis elbow. The laser used was a $904 \mathrm{~nm}$ GaAs laser, The dose utilized was $2-4 \mathrm{~J} / \mathrm{cm}^{2}$ (two sessions per week). Outcome measures used were grip strength, VAS and weight test. All the parameters showed improvement at the end of 8 weeks in the laser with plyometric exercise group as compared to the placebo group.

The study of Bjordal et al., [15] analyzed the anti-inflammatory action of low intensity laser through the concentration of inflammatory markers and found that its use increased blood flow (angiogenesis) in the area and reduced inflammation.

A study by Abrisham et al., [16] indicates that LLLT combined with exercise therapy is more effective than exercise therapy alone in relieving pain and in improving the shoulder joint ROM patients with subacromial syndrome (rotator cuff and biceps tendinitis). The results of our study and conclusions are similar to those of a recent systematic review published on the efficacy of conservative treatment of Achilles tendinopathy. Authors reported that there is moderate evidence that LT may provide improvement in terms of pain and shorten recovery period in patients complaining from Achilles tendinopathy Rowe et al., [17].

Also, the result of this study agreed with the study conducted by Keynoosh et al., [18] who concluded that LLLT can potentially be effective in treating tendon disorders when recommended parameters are used. Dangelo et al., [19] provided strong evidence that positive results are linked with the use of LLLT for the treatment of tendon disorders.
In another study by Sharma et al., [20] in which low level laser therapy and ultrasonic therapy were compared in the DQV subjects. Ga-As Al infrared laser wavelength $830 \mathrm{~nm}$ was used, and an optimum dose of 3 joules $/ \mathrm{cm}^{2}$ continuous output of $100 \%$ was given. After treatment, significant improvements were seen in both groups in the Ritchie's tenderness scale, grip strength and VAS.

Also, the result of this study agreed with a study by Haslerud et al., [21] who concluded that LLLT is a safe and effective option for pain managment in subjects with shoulder tendinopathy.

Also, the result of this study agreed with a study by Armagan et al. [22] "Effect of Low-Level Laser Treatment in DQV Patients" showed that There were no difference between the two groups in terms of VAS scores at baseline. Significant improvement was observed in post treatment VAS in two groups (Group 1; $p 0.05$ ). The grip strengths assessed at baseline were similar in all groups. Post treatment grip strength significantly improved in LLLT group ( $p>0.05)$.

\section{References}

1- McDERMOTT J.D., ILYAS A.M., NAZARIAN L.N. and LEINBERRY C.F.: Ultrasound-guided injections for de quervain's tenosynovitis. Clinical Orthopaedics and Related Research $\circledast$, 470 (7): 1925-1931, 2012.

2- GOUBAU J.F., GOUBAU L., VAN TONGEL A., VAN HOONACKER P., KERCKHOVE D., et al.: The wrist hyperflexion and abduction of the thumb (WHAT) test: A more specific and sensitive test to diagnose de Quervain tenosynovitis than the Eichhoff's test. J. Hand Surg. Eur., 39 (3): 286-292, 2014.

3- PATEL K.R., TADISINA K.K. and GONZALEZ M.H.: De Quervain's disease. Eplasty, 13: Ic52, 2013.

4- GOEL R. and ABZUG J.M.: De Quervain's tenosynovitis: A review of the rehabilitative options. Hand, 10 (1): 15,2015 .

5- STAHL S., VIDA D., MEISNER C., STAHL A.S., SCHALLER H.E. and HELD M.: Work related etiology of de Quervain's tenosynovitis: A case-control study with prospectively collected data. BMC Musculoskelet Disord, May 28; 16: 126, 2015.

6- ANDRÉU J.L., OTÓN T., SILVA-FERNÁNDEZ L. and SANZ J.: "Hand pain other than carpal tunnel syndrome (CTS): The role of occupational factors". Best Pract Res. Clin. Rheumatol., 25 (1): 31-42, 2011.

7- STAHL STÉPHANE, VIDA DANIEL, MEISNER CHRISTOPH, LOTTER OLIVER, ROTHENBERGER JENS, SCHALLER HANS-EBERHARD and STAHL ADELANA SANTOS: "Systematic Review and Meta-Analysis on the Work-Related Cause of de Quervain Tenosynovitis". Plastic and Reconstructive Surgery, 132 (6): 1479-1491, 2013.

8- HARWOOD P. and GIANNOUDIS P.V.: De quervain's tenosynovitis Practical procedures in orthopedic surgery (pp. 19-20): Springer, 2012. 
9- WARD A., ROBERTSON V., LOW J. and REED A.: [Physical therapy. Clinical and biophysical aspects. 1 st Polish edition]. Wroclaw: Edra Urban \& Partner; 2009 (in Polish). cases]. Ann. Chir. Plast. Esthet, 55 (1): $42-$ 45, 2009.

10- DE ANDRADE A.L., BOSSINI P.S. and PARIZOTTO N.A.: Use of low level laser therapy to control neuropathic pain: A systematic review. J. Photochem. Photobiol. B., 164: 36-42, 2016.

11- SHARMA R., AGGARWAL A.N., BHATT S., et al.: Outcome of low level lasers versus ultrasonic therapy in de Quervain's tenosynovitis. Indian J. Orthop., 49: 5428,2015 .

12- TUMILTY S., MUNN J., ABBOTT J.H., McDONOUGH S., HURLEY D.A. and BAXTER G.D.: Laser therapy in the treatment of achilles tendinopathy: A pilot study. Photomed Laser Surg., 26 (1): 25-30, 2008.

13- STERGIOULAS A., STERGIOULA M., AARSKOG R., LOPES-MARTINS R.A. and BJORDAL J.M.: Effects of low-level laser therapy and eccentric exercises in the treatment of recreational athletes with chronic achilles tendinopathy. Am. J. Sports Med., 36 (5): 881-887, 2008.

14- STERGIOULAS A.: Effects of low-level laser and plyometric exercises in the treatment of lateral epicondylitis. Photomed Laser Surg., 25: 205-13, 2010.

15- BJORDAL J.M., BENSADOUN R.J., TUNÈR J., FRIGO L., GJERDE K. and LOPES-MARTINS R.A.: A systematic review with meta-analysis of the effect of low-level laser therapy (LLLT) in cancer therapy-induced oral mucositis. Support Care Cancer, 19 (8): 1069-77, 2011.

16- ABRISHAM S.M.J., KERMANI-ALGHORAISHI M. GHAHRAMANI R., JABBARI L., JOMEH H. and ZARE M.: Additive effects of low-level laser therapy with exercise on subacromial syndrome: A randomised, doubleblind, controlled trial. Clinical Rheumatology, 30 (10): 1341-1346, 2011.

17- ROWE V., HEMMINGS S., BARTON C., MALLIARAS P., MAFFULLI N., et al.: Conservative management of midportion Achilles tendinopathy: A mixed methods study, integrating systematic review and clinical reasoning. Sports Med., 42: 941-967, 2012.

18- KEYNOOSH H. and ELAHEH M.: Comparison betweenKinesio Taping and Physiotherapy in the Treatment of De Quervain's Disease. J. Musculoskeletal Research, 16 (1): 6-8, 2013.

19- DANGELO K., SUTTON D., COTE P., DION S., WONG J.J.: The effectiveness of passive physical modalities for the management of soft tissue injuries and neuropathies of the wrist and hand: A systematic review by the Ontario Protocol for Traffic Injury Management (OPTIMa) Collaboration. J. Manipulative Physiol. Ther., 38 (2): 493 506.93, 2015.

20- SHARMA R., AGGARWAL A.N., BHATT S., et al.: Outcome of low level lasers versus ultrasonic therapy in de Quervain's tenosynovitis. Indian J. Orthop., 49: 542$8,2015$.

21- HASLERUD S., MAGNUSSEN L.H., JOENSEN J., LOPES-MARTINS R.A.B. and BJORDAL J.M.: The efficacy of low-level laser therapy for shoulder tendinopathy: a systematic review and meta-analysis of randomized controlled trials. Physiother Res. Int., 20 (2): 108-25, 2015.

22- ARMAGAN O., ORTANCA B., OZGEN M., BERKAN F. and ONER S.: Effect of Low-Level Laser Treatment in de Quervain's Tenosynovitis Patients, Osmangazi Journal of Medicine, 2020.

\section{تأثير الليزر منخفض الشدة على إلتهاب غمد أوتار الابهام بعد الولادة}

$$
\begin{aligned}
& \text { الخلفية العلمية: يعتبر مرض إلتهاب غمد أوتار الإبهام بعد الولادة حالة تسبب الألم وتئثر على الأنثطة اليومية والعناية بالطفل، وإنه من } \\
& \text { الضريدى تقليل نسبة الألم. } \\
& \text { هدف البحث: يهدف هذا البحث إلى توضيح تأثير الليز منففض الشدة على إلتهاب غمد أوتار الإبهام اللسيدات بعد الولادة. }
\end{aligned}
$$

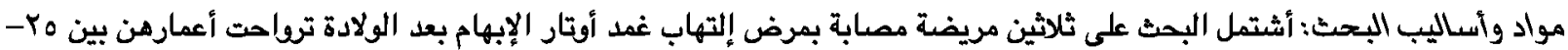

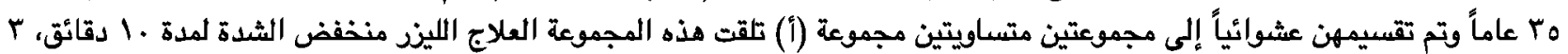

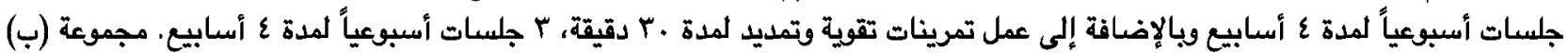

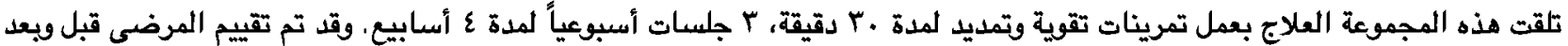

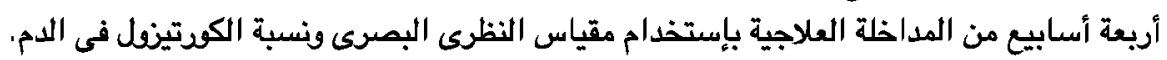

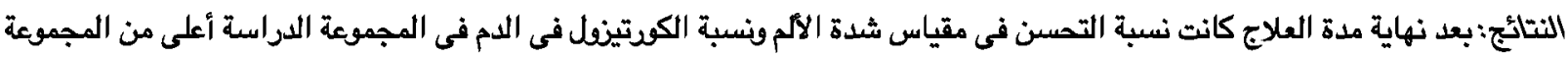

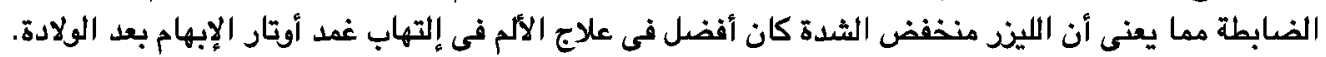

$$
\begin{aligned}
& \text { الاستتاج: نستخلص من نتائج البحث أن الليز منخفض الشدة ذو فاعلية فى تحسن الألم لدى السيدات اللآتى يعانين من إلتهاب غمد } \\
& \text { أوتار الإبهام بعد الولادة. }
\end{aligned}
$$

